Volume 9, No.4, July - August 2020

International Journal of Advanced Trends in Computer Science and Engineering

Available Online at http://www.warse.org/IJATCSE/static/pdf/file/ijatcse66942020.pdf

https://doi.org/10.30534/ijatcse/2020/66942020

\title{
Harmonic Distortion Analysis of ANFIS controlled PV fed three phase Voltage Source Converter
}

\author{
R. Padmavathi ${ }^{1}$, Dr. R. Kalaivani ${ }^{2}$, P.S. Maheswari ${ }^{3}$ and Dr.K.Premkumar ${ }^{4}$ \\ ${ }^{1}$ Assistant Professsor(SG),Department of EEE, Rajalakshmi Engineering College, Tamilnadu,India. \\ padmavathi.r@rajalakshmi.edu.in \\ ${ }^{2}$ Professsor, Department of EEE, Rajalakshmi Engineering College, Tamilnadu,India. \\ r.kalaivani@rajalakshmi.edu.in \\ ${ }^{3}$ Research Scholar,Department of EEE Sona college of technology, Tamilnadu,India. \\ mahe_rini@yahoo.co.in \\ ${ }^{4}$ Associate Professor, Department of EEE, Rajalakshmi Engineering College, Tamilnadu,India. \\ Premkumar.k@@rajalakshmi.edu.in
}

\begin{abstract}
An increasing demand for power and polluting fossil fuels has made the focus to move towards renewable energy systems (RES). Inspire of providing a clean and green energy, the renewable source suffers from intermittency and low power levels which have made the boost converters indispensable. The POSLC offers a viable option which uplifts the voltage level in geometric progression increasing the gain in power series. The $\mathrm{P} \& \mathrm{O}$ based MPPT method have been applied to track the maximum power. A power output obtained from a solar panel is given to the super-lift converter and the boosted output from the converter is converted to $\mathrm{AC}$ through a three phase VSC, which is fed to the grid after proper synchronization. This work presents a model of micro grid system connection for PV with RL load driving through LUO converters. The main challenges accompanying the integration of RES includes harmonic distortions and voltage fluctuations. To alleviate these PQ issues and to improve the performance of the grid, an ANFIS based controller has been instigated. SVPWM technique has been tailored for PWM production of VSI. The effectiveness of the modelled system is verified using MATLAB/Simulink.
\end{abstract}

Key words: ANFIS, LUO converter, $\mathrm{P} \& \mathrm{O}$ based MPPT, RES

\section{INTRODUCTION}

The consumption of electricity is rapidly increasing in today's world. The running out of petroleum and the increased global warming due to carbon emission has made world to move towards RES. In most part of the world the electricity is produced using coal /oil/Natural gas. However, these sources are highly expensive and also hazards to environment. Hence, the utilization of RES for power production is trending today in all over the world. This RES includes wind/solar energy.
These are referred as clean energy sources. These are referred as clean energy sources because they offer emission free environment. Among the various RES, solar is considered as more effective system because of its huge availability nature[1]. So it is widely utilized in most of the countries.

Thus, the voltage produced by the solar system depends upon the series/parallel arrangement of solar cells. It too many solar cells were utilized for higher voltage application, its size becomes more complex. Hence, only less number of $\mathrm{PV}$ array should be utilized for energy production. As a result, the output obtained from PV is less which is not enough to fed the load. Hence, to improve the voltage level of output (ie. PV), boost converters were employed [28-30].

One among such converter is a Luo converter. This converter provides high power density with ripple content [25]. There are four different forms of LUO converter are examined[13]. Based on their boundary conditions and gains (voltage transfer), positive output super lift converter is chosen to enhance the output from PV.

Thus, to control the operation of proposed converter, controller has to be implemented. However, conventional PI controllers are failed to regulate the voltage across the DC bus under dynamic operating condition. Hence at this condition, AI controllers like Fuzzy/Neuro can be implemented to avoid unregulation. In fuzzy control technique, mamdani and Takagi-sugeno (TS) were reported. They are formulated on the basis of rules. But no standard method is available for rule base. Moreover, to minimize the error, membership functions(MFs) has to be tuned. Hence, to eliminate these limitations of both conventional and AI controllers, an hybrid AI controller (ANFIS ) is proposed in this work for regulating the voltage level of Luo converter.

ANFIS is the combination of neural network (NN) and FLC. Hence, it provides dual advantage in a system. In [25] ANFIS controller is incorporated with several inverters and hence, the total cost was reduced.

In [26] ANFIS controlled UPQC is modeled and hence, its efficiency was increased. In this, TS control is implemented 
for DC bus and thus, ANFIS enhances a better voltage regulation with lower complex while implementing.

In[27], ANFIS was implemented to control the operation of STATCOM. Thus, it exhibits higher accuracy and it achieves higher active power along with compensation of reactive power.

Hence, the principal objective of this proposed system is depicted as follows.

1. Regulation of DC link voltage of an inverter by ANFIS controller. Hence, it is designed in such a way to after higher efficiency during variation in either load/generated power.

2.To alleviate power quality problems occurred due to nonlinear/unbalanced loads.

3.To retain a balanced $3 \phi$ voltage at PCC even under unbalanced load, condition.

4. To maintain unity power factor $(\mathrm{PF})$ and there by sustains both active and reactive power in phase under all conditions

\section{SYSTEM DEFINITION}

The schematic representation of the suggested system is defined in Figure. 1.

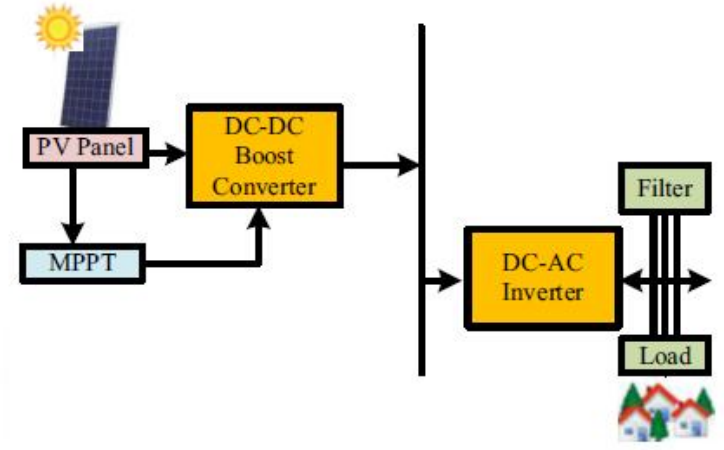

Figure 1: Schematic Representation of the suggested system

\section{DESIGN OF PV SYSTEM}

Solar cells together forms PV module. Usually they are organized either in parallel/series on the basis of its applications. Solar cell was symbolized as a current source (Is) with inverted diode and are arranged in parallel combinations. Thus each cell exhibits its individual series $\left(R_{s}\right)$ and parallel $(R p)$ resistance. The Rs is due to interruption in the pathway of current and $\mathrm{Rp}$ is due to leakage current [10-13] and the same is represented in figure 2.

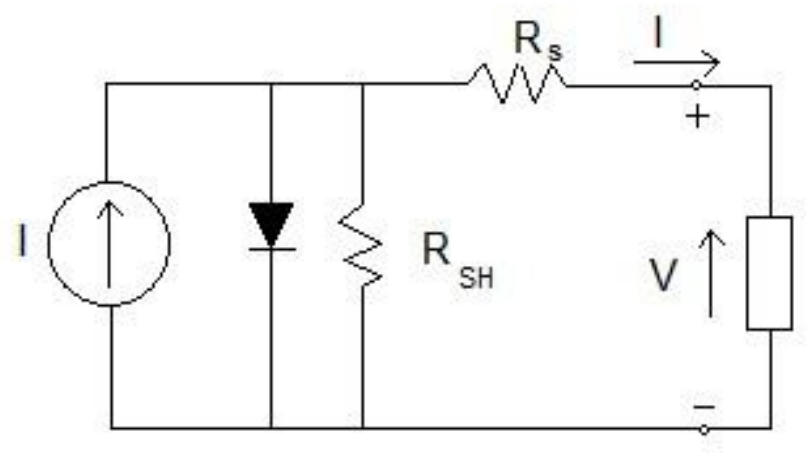

Figure 2: PV cell Model

However, in this projected model, $\mathrm{R}_{\mathrm{s}}$ is very high. Hence, it is omitted and it has no significant role in the circuit. The output current derived from PV is derived as $I=I_{w}-I_{d}$

But due to varying nature of weather, the PV gets affected. So an active tracking topology is indispensable to extract maximum amount of power from a PV module.

\section{MPPT Algorithm}

Thus, MPPT technique was adopted to obtain maximum of power from a PV module [2-9]. Among those, P\&O topology is widely utilised in PV based system. It's mainly due to its higher efficiency and simplicity.

Thus, the flow chat of P\&O technique is displayed in figure 3.

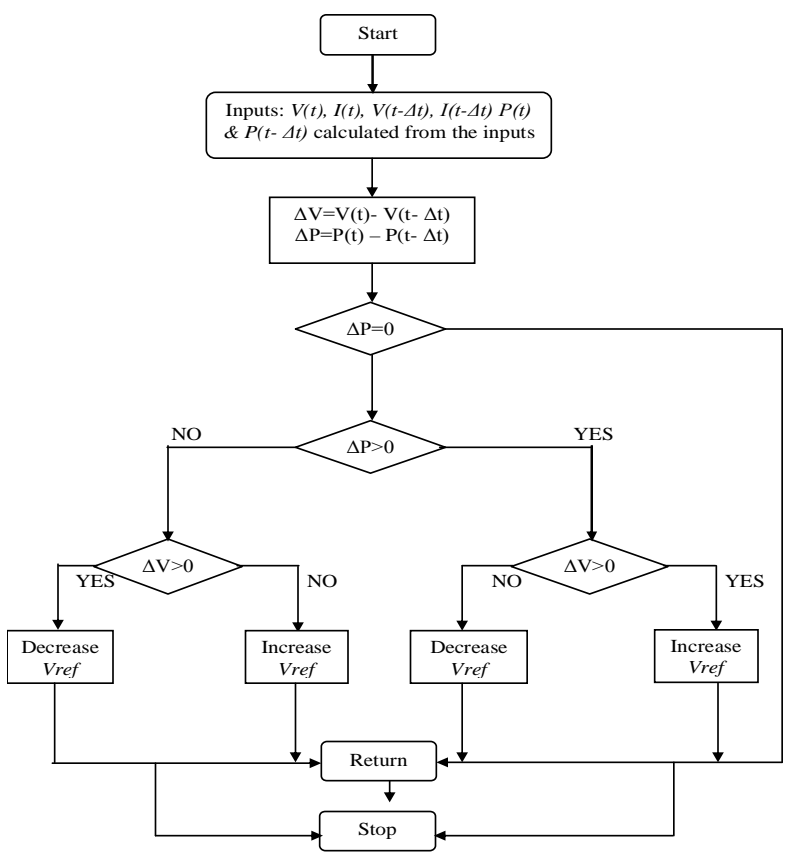

Figure 3: Flow chart of P\&O technique

The switch $\mathrm{S}$ acts as a main switch and $\mathrm{Si}$ as a slave. These two switches (S, S1) operate in push-pull condition and its operation is depicted in figure 4 and 5 . 
R. Padmavathi et al., International Journal of Advanced Trends in Computer Science and Engineering, 9(4), July - August 2020, 4650 - 4656

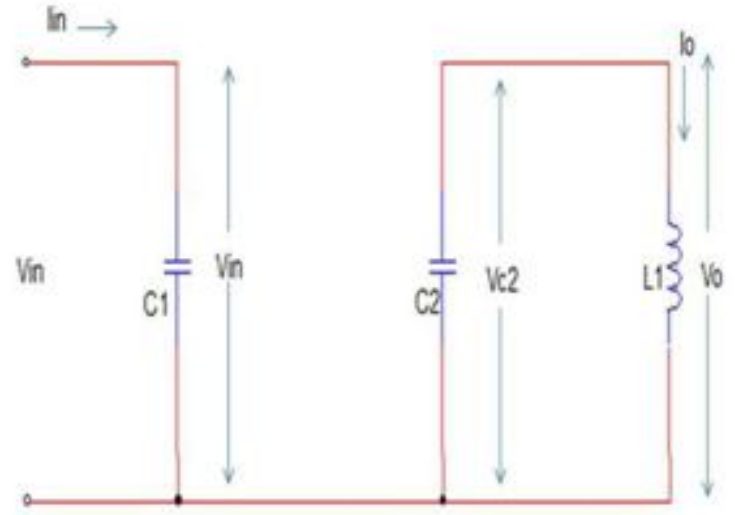

Figure 4: Circuit operation when switch is $\mathrm{ON}$

When ' $\mathrm{S}$ ' is in on condition, the voltage across the capacitor (C1) is $\mathrm{V}_{\text {in }}$ and the switch ' $\mathrm{S} 1$ ' remains off.

When ' $\mathrm{S}$ ' is in OFF condition and ' $\mathrm{S} 1$ ' remains $\mathrm{ON}$, then the voltage across $\mathrm{C} 2$ is $\mathrm{V}_{\mathrm{o}}$.

Where Therefore, output voltage,

$V_{o}=2 V_{\text {in }}$

However under practical,

$V_{0}=2 V_{n}-\Delta V_{1}$

$V_{0}=2 V_{\text {in }}-\left(V_{D_{1}}+V_{D_{2}}+V_{s 1}+V_{2}\right)$

$V_{0}=2 V_{n}-\left(2 V_{s}+2 V_{o}\right)$

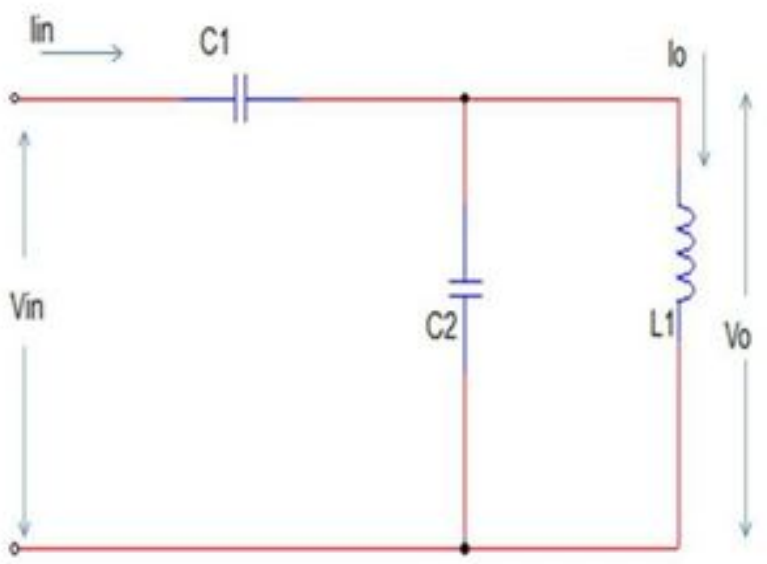

Figure 5: Circuit operation when switch is OFF

From the above equations, it is concluded that due to some component losses, the output voltage will always be lower than twice of an input voltage.

\section{Design of ANFIS controller}

ANFIS operates by applying learning methods of neural network to fuzzy inference system. A two input one output ANFIS structure is considered as shown in figure 6. It consists of some set of rules and six distinct layer which makes it a multilayer network.

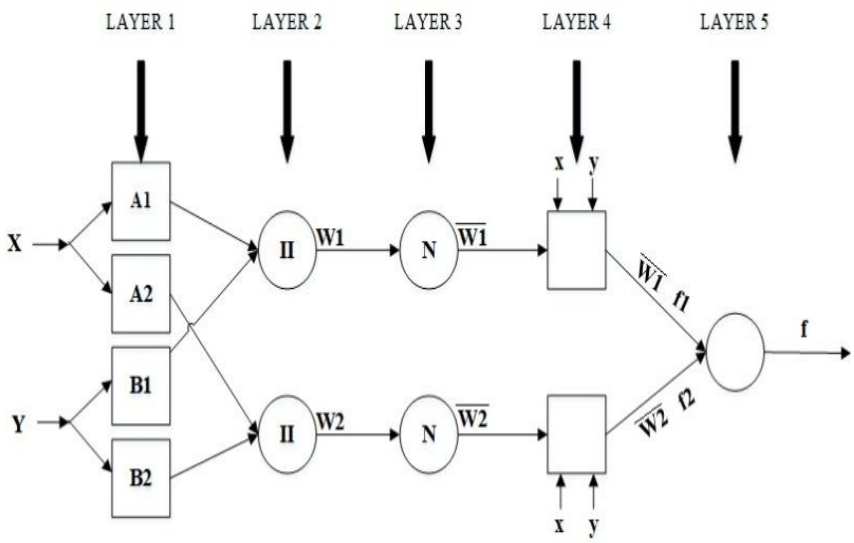

Figure 6: Sugeno type FIS structure with two input and two output

IF-Then Rules of Takagi-Sugeno model:

Rule 1 : if zl is $A_{1}$ and $z 2$ is $B 1$;

Then $F 1=a_{1} z_{1}+b_{1} z_{1}+c_{1}$

Rule 2 : if $z 1$ is $A_{2}$ and $z 2$ is $B 2$;

Then $F 2=a_{2} z_{1}+b_{2} z_{2}+c_{2}$

Layer 1: Acts as the input layer. Degree of membership of every inputs are computed using a Bell Membership function.

$\mu_{A} Z=g b \in \|\left(\sigma, a_{i}, b_{i}, c_{i}\right)=\frac{1}{1+\left|\frac{z_{i}-c_{i}}{a_{i}}\right|}$

Where

$a_{i} ; b_{i} ; c_{i}$ - Parameter set

c - Center of the function.

The parameters $b$ and a are used to control the membership crossovers.

Layer 2: At the Fuzzification layer in the product node incoming signals are multiplied and firing strength of each rule is obtained as output.

$w_{i}=\mu A_{i}(x), \mu B_{i}(y), i=1,2$

Layer 3: Individual Rule's Strength is normalized in this layer. Output node(s) is the representation of proportion of firing strength of the $i^{\text {th }}$ rules to the summation of firing strengths of all rules.

$\overline{w_{1}}=\frac{w_{i}}{w_{1}+w_{2}}, i=1,2$

Layer 4: This is a adaptive node which determines the consequent parameters using the following function.

$\bar{w}_{i} f=\bar{w}_{L}\left(p_{i}+q: y+n\right)$

Normalized firing strength $\bar{w}_{\mathrm{l}}$ is obtained from layer3 whereas $p_{\mathrm{i}}, q_{\mathrm{i}}$, and $\boldsymbol{n}_{\mathrm{I}}$ are the parameters of this node.

Layer 5: Finally, output of the system is the summation of inputs in a single node in this Rule inference layer.

Overall output $=\sum_{i} \bar{w}_{i} f=\frac{\sum_{i} w_{i} f_{i}}{\sum_{i} w_{i}}$

(10)

The inputs to the fuzzifier section of ANFIS controller are change in error (ce) and error (e). The MF of the inputs are chosen as Gaussian MF and are categorized into 7 functions 
namely (NL, NA, NM, Z, PM, PA, PL). The defuzzifier section generates the duty cycle $(\mathrm{d})$ which is a linear signal in ANFIS model.

The inputs are given to the ANFIS controller after being fuzzified using the fuzzy sets. To select proper set of rules which gives optimal output the neural network is trainned. Then the selected rules are fired to get the required control signal[31]. The structure of the ANFIS controller is shown in Figure 7.

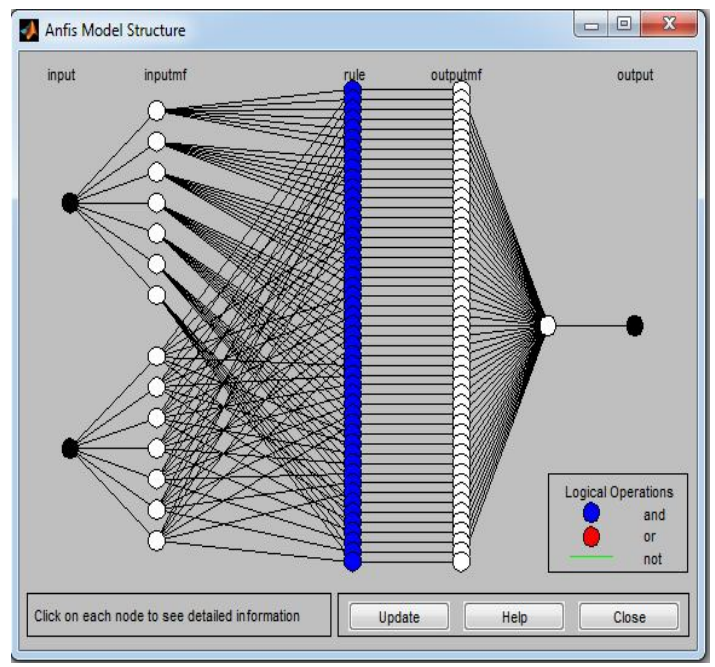

Figure 7: ANFIS Structure

The rule base of proposed ANFIS is depicted in figure $8 \mathrm{a}$.

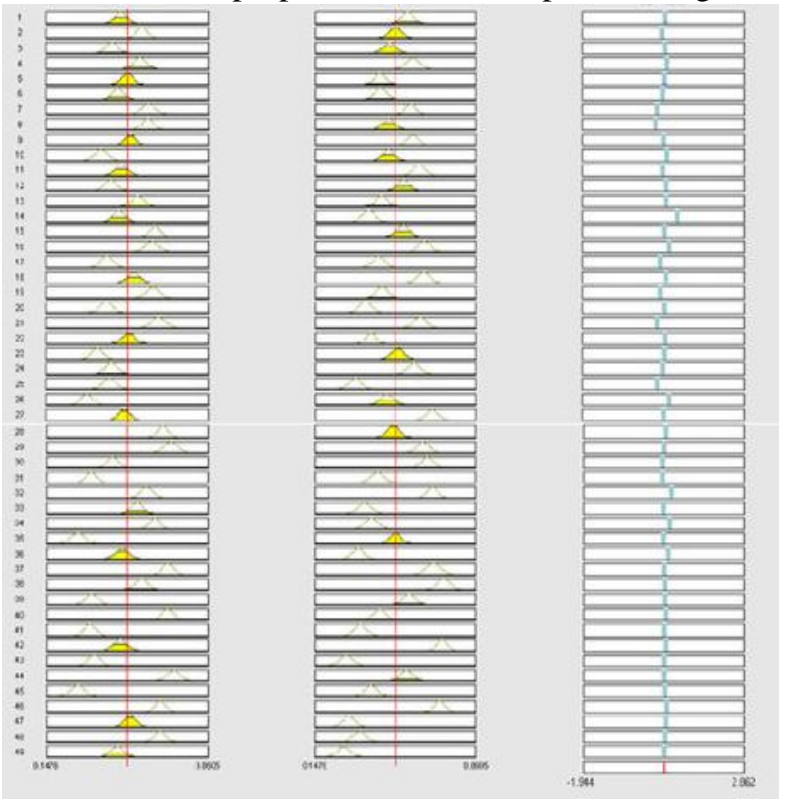

Figure 8a: Rule base - ANFIS

Figure 7 depicts the ANFIS model structure with two input neurons, four hidden layers viz., input membership function, membership function, rule base and aggregated output and one output neuron. The developed ANFIS controller is trained to select proper and optimal rules from the 132 fuzzy rules. Individually both the input neurons are connected to 7 rules i.e., 7 by 7 rules is available for hidden layers. The e and ce are applied to the 1 st hidden layer of the ANN. Optimal set of 49 fuzzy rules are identified and selected in the $2^{\text {nd }}$ and $3^{\text {rd }}$ layers. The $4^{\text {th }}$ layer fires the most favorable rule out of 49 rules. Then the output is defuzzified at output neuron which in turn is used to generate the firing pulse for the converter.

Thus the surface view of rule base after training is illustrated in Figure 8b.

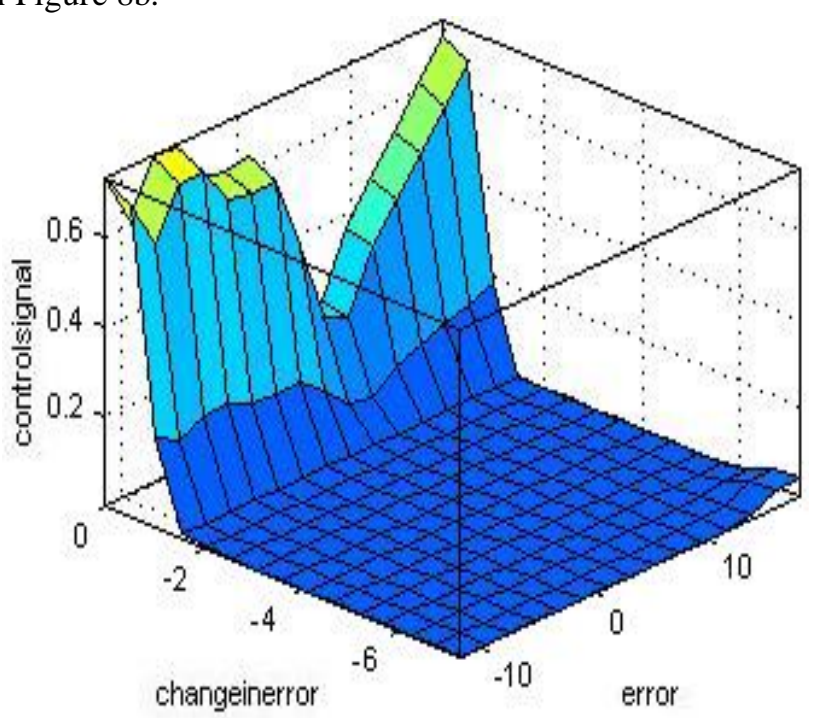

Figure 8b: ANFIS rule base surface view

Thus the output of ANFIS controlled Luo converter is fed to the inverter. A $3 \Phi$ VSI is utilized here for DC/AC conversion and is depicted in figure 9.

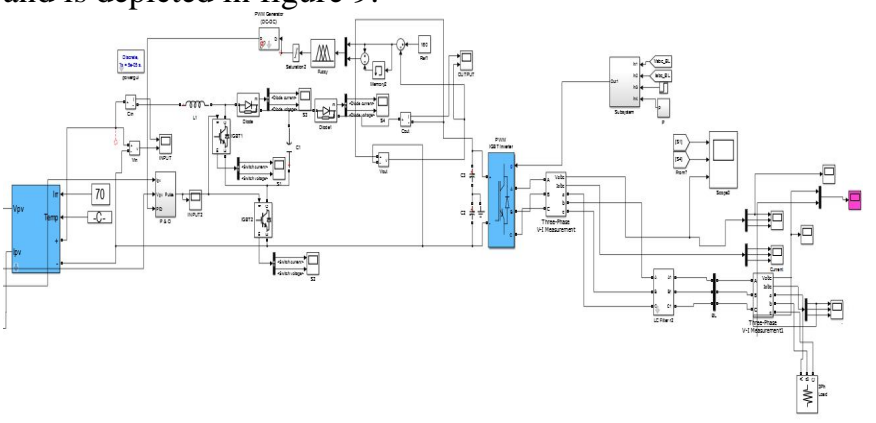

Figure 9: Simulation Circuit of Luo converter fed three phase VSC

\section{Control of inverters}

The efficiency of an inverter mainly depends upon the modulation approaches which controls the inverter[14-16]. In this design, SPWM technique has been tailored to control the inverter.

In this technique, the sinusoidal AC reference voltage (Vref) is compared with the triangular carrier wave ( Vc) which governs switching states of an inverter. [17-19]. Thus, the switching state can be determined as follows

-When Vref $>$ Vc, upper switches are on

- When Vref< Vc, lower switches are turned on [20-24]. 


\section{RESULTS AND DISCUSSION}

Thus the effectiveness of the suggested system under power flow management is power flow management is analyzed using MATLAB simulation. Thus the effectiveness, this model is analyzed under varying load condition.

The LUO converter $I_{\text {out }}$ and $V_{\text {out }}$ are given in Figure 10.
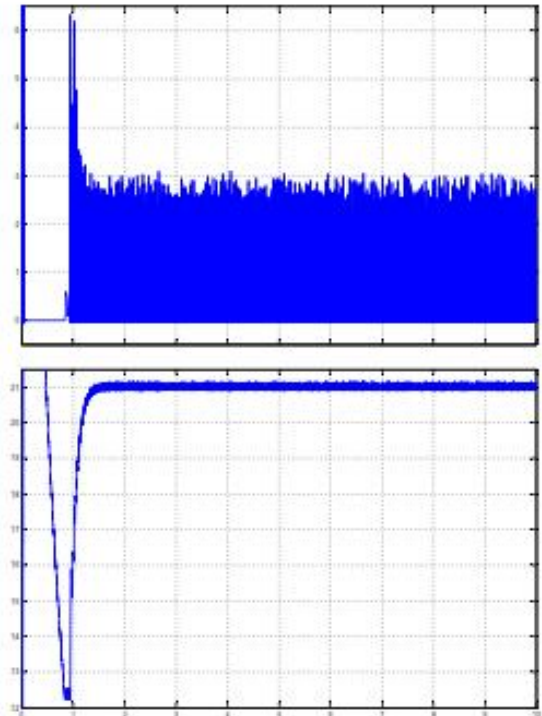

Figure 10a: LUO converter Iout and Vout (with PI controller)
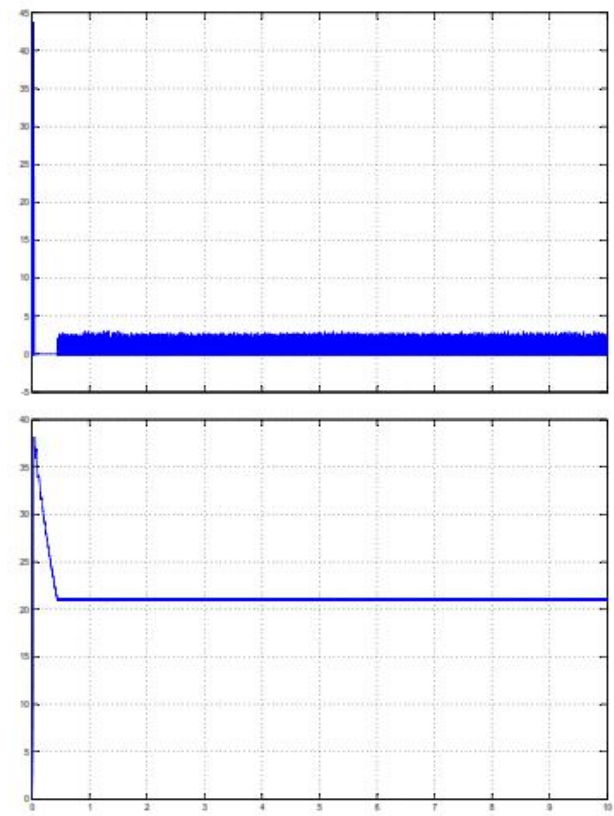

Figure 10b: LUO converter Iout and Vout (with ANFIS controller)

Figure 10a and $10 \mathrm{~b}$ describes depicts the performance of PI and ANFIS controller in the suggested system. From the analysis, it is proven that ANFIS exhibits better regulation in terms of voltage. Simultaneously, the tracking capability of ANFIS is high which can observed from its reduced settling time than that of PI controller under varying load condition. From the graph view, it is observed that the setting time $\left(\mathrm{T}_{\mathrm{s}}\right)$ of ANFIS is only about $0.5 \mathrm{~s}$ where as in PI, it is about $1 \mathrm{sec}$. conversely, there is no undershoot while implementing ANFIS. Figure 11 shows that the voltage from the inverter which remains in balanced condition and is sinusoidal irrespective of the nature of the applied load.
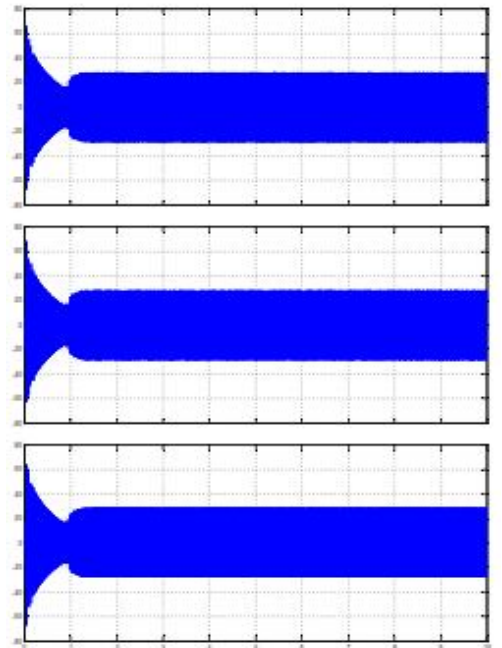

Figure 11a: System response under PI controller
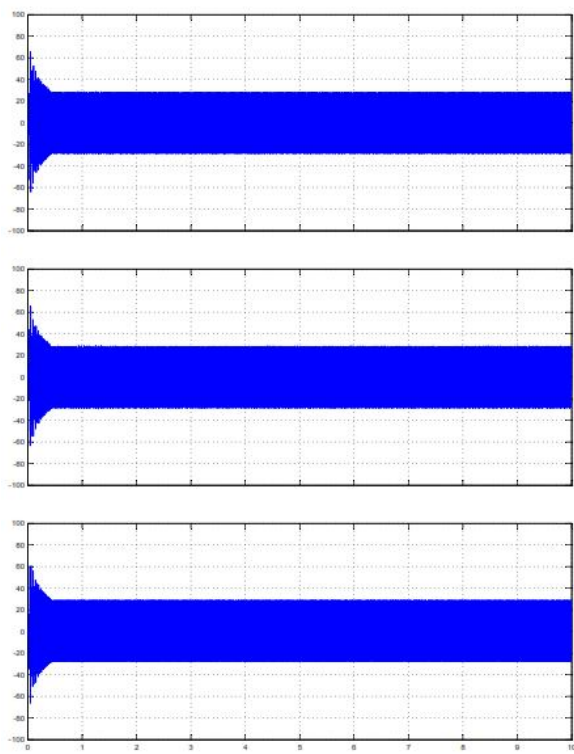

Figure 11b :System response under ANFIS controller

While integrating RES with grid, the power quality measures play a major role. Thus, the harmonic distortion has to be measured to ensure the efficiency of the system. Thus, from the figure 12a and $b$, the THD of the system under different controller were observed. From the THD analysis, it is seen that ANFIS exhibits 2.37\% of THD where as it is about $7.22 \%$ for PI controller. Hence, it is concluded that ANFIS will suppress the harmonics present in the system to a considerable limit. 


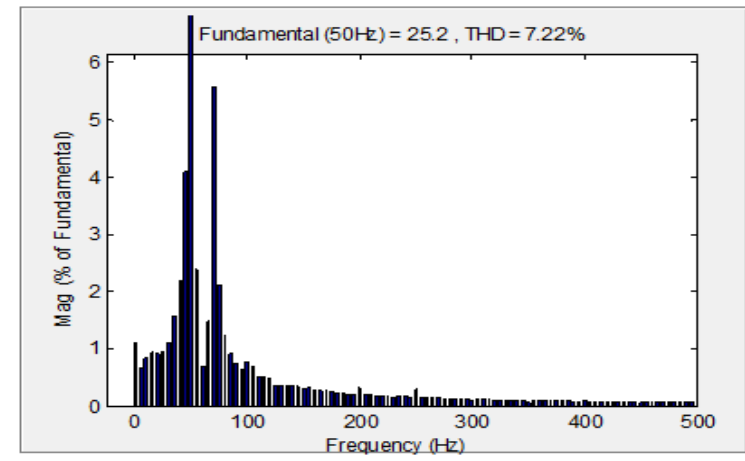

Figure 12a. THD analysis under PI controller.

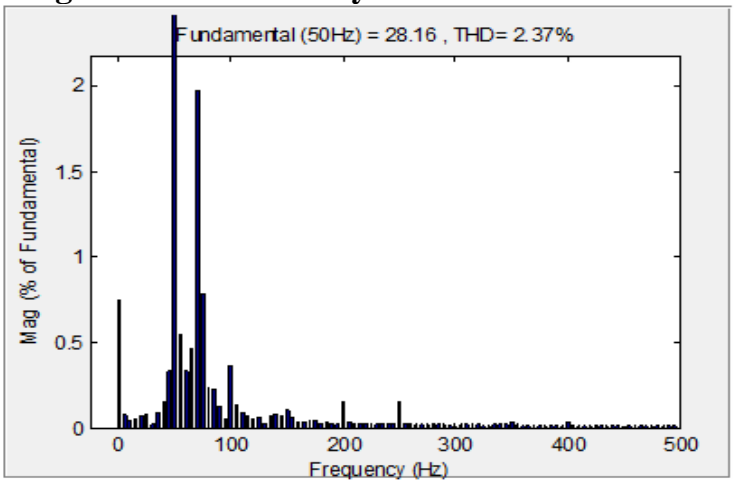

Figure 12b: THD analysis under ANFIS controller

Finally, from all these, it is concluded that the suggested system can appropriately responds to all variations in load with improved power quality performance.

\section{CONCLUSION}

This study made an attempt to design micro grid application for industry/ rural area. In this perception, this work formulated an efficient system using PV source along with LUO converter. In this system, a constant power is supplied to load by maintaining constant irradiation and temperature value. Thus, under these operating conditions, the output voltage obtained using LUO converter is incorporated to AC load through VSI. SPWM topology is incorporated to produce PWM signals. From the analysis, it is concluded that Luo converter can be successfully implemented for such micro $t$ grid applications. Thus, the outcomes of this work can be concluded as follows:

- Simulation results portrays that the proposed ANFIS controller shows an improved performance in terms of regulation of DC link voltage with quick dynamic response.

- Comparative study of ANFIS controller over PI controller have been demonstrated.

- The control scheme of an inverter was established using SPWM and thus it reduces the THD of system within 5\% stipulated limit.

- The suggested control structure can be generalized for all type of RES without any change in control scheme.

\section{REFERENCES}

1. Seddik, M, Zouggar, S, Ouchbel, T, Oukili, M, Rabhi, A, Aziz, A \& Elhafyani, ML. A stand-alone system energy hybrid combining the wind and photovoltaic with voltage control (loop feedback voltage). International Renewable Energy Congress, Tunisia, pp. 227-232, 2010.

2. Salas, V, Olias, E, Barrado, A \& Lazaro. A Review of the maximum power point tracking algorithms for stand-alone photovoltaic systems, Solar Energy Mat Sol C, vol. 90, no. 11, pp.1555-78, 2006.

https://doi.org/10.1016/j.solmat.2005.10.023

3. Esram, T \& Chapman, PL. Comparison of photovoltaic array maximum power point tracking techniques, IEEE $T$ Energy Converter, vol. 22, no. 2, pp. 439-49, 2007.

4. Zegaoui, A, Aillerie, M, Petit, P, Sawicki, JP, Jaafar, A, Salame, C \& Charles, JP. Comparison of two common maximum power point trackers by simulating of $\mathbf{P V}$ generators, Energy Procedia, vol. 6, pp. 678-87, 2011.

https://doi.org/10.1016/j.egypro.2011.05.077

5. Bhatnagar, P \& Nema, RK . Maximum power point tracking control techniques: State-of-the-art in photovoltaic applications, Renew Sust Energy Rev, vol. 23, pp. 224-41, 2013.

6. Rekioua, D, Achour, AY \& Rekioua, T. Tracking power photovoltaic system with sliding mode control strategy, Energy Procedia, vol. 36, pp. 219-30, 2013.

7. Mirbagheri, SZ, Mekhilef, S \& Mirhassani, SM . MPPT with Inc. Cond method using conventional interleaved boost converter, Energy Procedia, vol. 42, pp. 24-32, 2013. 8. Hohm, DP \& Ropp, ME . Comparative Study of Maximum Power Point Tracking Algorithms, Progress in Photovoltaic Research and Applications, vol. 11, pp. 47-62, 2002.

9. Xiao, W . A modified adaptive hill climbing MPPT method for photovoltaic power Systems, Master's thesis, Shenyang Polytechnic University, Vancouver, Canada. 1991. 10.F. J. Vorster and E. E. Van Dyk. Current-voltage characteristics of high-concentration, photovoltaic arrays, Progress in Photovoltaics: Research and Applications, vol. 13, no. 1, pp. 55-66, 2005.

11.Enrique, JM, Andujar, JM \& Bohorquez, MA. A reliable, fast and low-cost maximum power point tracker for photovoltaic applications, Solar Energy, vol. 84, pp. 79-89, 2009.

https://doi.org/10.1016/j.solener.2009.10.011

12. Salas, V, Olias, E, Barrado, A \& Lazaro, A . Review of the maximum power point tracking algorithms for stand-alone photovoltaic systems, Solar Energy Materials \& Solar Cells 90, pp. 1555-1578, 2006.

13.Luo, FL \& Ye, H . Advanced DC/DC converters, New York, Washington D.C, USA, CRC Press. 2004.

14. Vural, A. M. PSCAD modelling of a two-level space 
vector pulse width modulation algorithm for power electronics education, Journal of Electrical Systems and Information Technology, 3(2), 333-347, 2016.

15. Wanchai, S. A Comparative Study of Sinusoidal PWM and Third Harmonic Injected PWM Reference Signal on Five Level Diode Clamp Inverter, Energy Procedia, 89, 137-148, 2016.

https://doi.org/10.1016/j.egypro.2016.05.020

16. Guoqiang, C., Jianli, K., \& Junwei, Z. . Numeric analysis and simulation of space vector pulse width modulation, Advances in Engineering Software, 65, 60-65, 2013.

17. Durgasukumar, G., \& Pathak, M. K.. Comparison of adaptive Neuro-Fuzzy-based space vector modulation for two-level inverter. Electrical Power and Energy Systems, 38, 9-19, 2012.

18. Colak, I., \& Kabalci, E.. Developing a novel sinusoidal pulse width modulation (SPWM) technique to eliminate side band harmonics, International Journal of Electrical Power \& Energy Systems, 44, 861-871, 2016.

19. Gopalakrishnan, K. S., \& Narayanan, G.. Space vector based modulation scheme for reducing capacitor RMS current in three-level diode-clamped inverter. Electric Power Systems Research, 117, 1-3, 2014.

https://doi.org/10.1016/j.epsr.2014.06.025

20.Jesmin F. Khan, S.M. . Space vector PWM for a two-phase VSI, Electrical Power and Energy Systems, 51, 265-277, 2013.

21.Oka, K., \& Matsuse, K.. A novel PWM technique with switching-loss reduction for independent drive of two 3-phase AC motors fed by a five-leg inverter, IEEJ Transactions on Electrical and Electronic Engineering, 6, 260-265, 2011.

22. Kumar RR, Kumar S, Yadav A . Comparison of PWM technique and inverter performance, IOSRJEEE, pp. 18-22, 2013

https://doi.org/10.9790/1676-0411822

23. J. Rocabert, A. Luna, F. Blaabjerg, P. Rodriguez. Control of power converters in AC microgrids, IEEE Trans. Power Electron.27, 4734-4749,2012.

24.R. Karthikeyan , Dr.A.K. Parvathy, S. Priyadharshini. Energy Optimization of Residential Energy Management in Micro Grid using Cyber Physical Controller, International Journal of Advanced Trends in Computer Science and Engineering, Volume 9 No.2, March -April 2020.

https://doi.org/10.30534/ijatcse/2020/41922020

25. Shan, Zeng-li, Shuo Liu, and Fang-lin Luo. Investigation of a super-lift luo-converter used in solar panel system,In 2012 China International Conference on Electricity Distribution, pp. 1-4. IEEE, 2012.

26.S. Gupta, R. Garg, A. Singh. TSFLC based DC link voltage regulation of grid connected DC micro grid,Int. J. Power Electron.9(3), 229-249, 2018.
https://doi.org/10.1504/IJPELEC.2018.093378

27. B. Singh, P. Jayaprakash, D.P. Kothari . New control approach for capacitor supported DSTATCOM in three-phase four wire distribution system under non-ideal supply voltage conditions based on synchronous reference frame theory,Int. J. Electr. Power Energy Syst. 33(5), 1109-1117,2011.

28. R.Padmavathi,Dr. R Kalaivani. Performance Analyses of DC-DC Converter with Controller for PV Application, Int.l Journal of Recent Technology and Engineering 8(3) 7507-751

29. V Veerapandiyan S Kanimozhi, D Mary. Performance analysis of sepic and zeta converter with fuzzy logic controller for maximum power point tracking, Int. Journal of Applied Engineering Research,Volume 10, 281-287

30. R. Padmavathi, M . Dhivyya Dharshinii. Study of Interleaved LLC Resonant Converter Operating at Constant Switching Frequency Using SCC, International Journal of Innovations in Engineering and Technology,8(1),2017.

https://doi.org/10.21172/ijiet.81.049

31. Dr. Kiran Ramaswamy, Dr. Dayanand Lal.N, Mr. Parikshith Nayaka S K, Mrs. Veena.R.C, Dr. Brahmananda S H. Fuzzy Logic Based Proportional Integral Control of Frequency for Small, International Journal of Advanced Trends in Computer Science and Engineering, Volume 9 No.2, March -April 2020.

https://doi.org/10.30534/ijatcse/2020/57922020 